\title{
Reduction of nitrogen compounds in oceanic basement and its implications for HCN formation and abiotic organic synthesis Nils G Holm* and Anna Neubeck
}

\author{
Address: Department of Geology and Geochemistry, Stockholm University, Stockholm, Sweden \\ Email: Nils G Holm* - nils.holm@geo.su.se; Anna Neubeck - anna.neubeck@geo.su.se \\ * Corresponding author
}

Published: 22 October 2009

Geochemical Transactions 2009, 10:9 doi:10.1186/1467-4866-10-9
Received: 7 April 2009

Accepted: 22 October 2009

This article is available from: http://www.geochemicaltransactions.com/content//0/I/9

(C) 2009 Holm and Neubeck; licensee BioMed Central Ltd.

This is an Open Access article distributed under the terms of the Creative Commons Attribution License (http://creativecommons.org/licenses/by/2.0), which permits unrestricted use, distribution, and reproduction in any medium, provided the original work is properly cited.

\begin{abstract}
Hydrogen cyanide is an excellent organic reagent and is central to most of the reaction pathways leading to abiotic formation of simple organic compounds containing nitrogen, such as amino acids, purines and pyrimidines. Reduced carbon and nitrogen precursor compounds for the synthesis of $\mathrm{HCN}$ may be formed under off-axis hydrothermal conditions in oceanic lithosphere in the presence of native $\mathrm{Fe}$ and $\mathrm{Ni}$ and are adsorbed on authigenic layer silicates and zeolites. The native metals as well as the molecular hydrogen reducing $\mathrm{CO}_{2}$ to $\mathrm{CO} / \mathrm{CH}_{4}$ and $\mathrm{NO}_{3}{ }^{-} / \mathrm{NO}_{2}{ }^{-}$to $\mathrm{NH}_{3} / \mathrm{NH}_{4}{ }^{+}$are a result of serpentinization of mafic rocks. Oceanic plates are conveyor belts of reduced carbon and nitrogen compounds from the off-axis hydrothermal environments to the subduction zones, where compaction, dehydration, desiccation and diagenetic reactions affect the organic precursors. $\mathrm{CO} /$ $\mathrm{CH}_{4}$ and $\mathrm{NH}_{3} / \mathrm{NH}_{4}{ }^{+}$in fluids distilled out of layer silicates and zeolites in the subducting plate at an early stage of subduction will react upon heating and form $\mathrm{HCN}$, which is then available for further organic reactions to, for instance, carbohydrates, nucleosides or even nucleotides, under alkaline conditions in hydrated mantle rocks of the overriding plate. Convergent margins in the initial phase of subduction must, therefore, be considered the most potent sites for prebiotic reactions on Earth. This means that origin of life processes are, perhaps, only possible on planets where some kind of plate tectonics occur.
\end{abstract}

\section{Background}

Geochemically plausible abiotic synthesis pathways and concentration mechanisms for nitrogen-containing molecules must eventually be found since nitrogen-based life is likely to have existed on Earth from early Archean onwards [1]. High ammonium contents (54-95 ppm) have been found in authigenic clays of the Isua supracrustal rocks of Western Greenland, suggesting that clays were major sinks of $\mathrm{NH}_{4}{ }^{+}$or other nitrogen compounds on the Earth's surface already at $3800 \mathrm{Ma}$ [2]. Ward and Brownlee have argued that plate tectonics is necessary for the origin of life on terrestrial planets and have listed a number of reasons in support of their opinion [3]. However, one argument that they have never mentioned is the connection between plate tectonics, hydrothermal geochemistry and reduction of simple carbon and nitrogen compounds suitable for abiotic organic chemistry. In our opinion, the best location where such processes could occur would be at convergent margins during the early phases of subduction of oceanic plates.

\section{Palagonitization}

Incipient alteration of mafic volcanic rocks (basalt; 45$52 \% \mathrm{SiO}_{2}$ ) entails the palagonitization of glass with con- 
comitant crystallization of authigenic layer silicates (e.g. smectites, double layer hydroxides) and zeolites [4-6]. Zeolites like phillipsite coexist with smectite and almost always with mafic glass [7]. The term palagonite is normally used in reference to a bulk sample of metabasite which contains a mixture of palagonitized glass, authigenic minerals like smectite, corrensite, zeolites, carbonates and $\mathrm{Fe}$-Ti oxides and phosphates, as well as primary minerals like plagioclase feldspars, clinopyroxene and olivine [4]. Minerals with expanding-contracting sheet structures like double layer hydroxides (DLH) are capable of accommodating molecules of virtually any size and clamping the layer of sorbed reactant ions, and are found to have particularly high catalytic activity [1]. DLH may be formed by replacing a fraction of the divalent $\mathrm{Mg}^{2+}$ in single layer magnesium hydroxide (brucite, $\mathrm{Mg}\left(\mathrm{OH}_{2}\right)$ ) with common trivalent cations such as $\mathrm{Al}^{3+}, \mathrm{Fe}^{3+}$ and $\mathrm{Cr}^{3+}[1,8]$. Brucite is a weathering product of olivine and pyroxene and constitutes the trioctahedral sheets of layer silicates (see section 'Serpentinization of olivine' below).

\section{Circulation of seawater in mafic rocks}

Seawater is constantly circulating through oceanic basement as a low-temperature fluid $\left(<150^{\circ} \mathrm{C}\right)$ [9]. Passive off-axis hydrothermal convection of seawater in older crust is in general a Rayleigh-Benard type circulation driven by the heat flow from the underlying, cooling crust [10]. Convection even in quite old crust is, however, in most cases still related to the original convection at the spreading ridge axis, although off-axis hydrothermal systems driven by exothermic hydration processes do exist in ultramafic rocks $\left(<45 \% \mathrm{SiO}_{2}\right)$. One example is the Lost City hydrothermal system near the Mid-Atlantic Ridge $[11,12]$. Results from the Ocean Drilling Program (ODP) Leg 201 (figures 1, 2 and 3) reveal that fresh seawater is channeled upwards into deep-sea sediments from the rocks underneath $[13,14]$. This happens still $40 \mathrm{Ma}$ or more after formation of the basement and is illustrated by the concentration profiles of dissolved nitrate in sediment porewater from ODP Sites 1225 and 1231 (figure 3). Similar profiles have been obtained for dissolved sulfate. The circulation of modern seawater with oxidants like nitrate and sulfate into basement is driven by thermal advection with diffuse recharge and focused discharge through basement high to the seafloor [15]. This means that nitrogen that has been oxidized at the Earth's surface may be continuously transported by ocean water down into reducing environments of mafic or ultramafic rocks in oceanic basement. On the early Earth, oxidized nitrogen compounds $\left(\mathrm{NO}_{2}{ }^{-}\right.$and $\left.\mathrm{NO}_{3}{ }^{-}\right)$may have been formed from $\mathrm{N}_{2}$ in a redox neutral atmosphere by lightning, corona discharge and impacts and subsequently transported by fluid circulation into reducing environments of the lithosphere [16].

\section{Nitrogen reduction in oceanic basement}

Systems containing $\mathrm{NH}_{3} / \mathrm{NH}_{4}{ }^{+}$are more efficient in abiotic organic synthesis than those dominated by $\mathrm{N}_{2}$ in both aqueous and gaseous environments [16]. Among aqueous environments, hydrothermal systems represent regions of the highest $\mathrm{NH}_{3}$ conversion rates and stability on the Earth [17]. Hydrothermal experiments have shown that $\mathrm{NO}_{2}{ }^{-}$and $\mathrm{NO}_{3}{ }^{-}$are converted to $\mathrm{NH}_{4}{ }^{+}$more rapidly than $\mathrm{N}_{2}$ [16]. Reduction of $\mathrm{N}_{2}, \mathrm{NO}_{2}{ }^{-}$and $\mathrm{NO}_{3}{ }^{-}$to $\mathrm{NH}_{4}{ }^{+}$is catalyzed by elemental $\mathrm{Ni}$ and $\mathrm{Fe}$ in the form of native metals or alloys. They can form in hydrothermal systems from $\mathrm{Ni}$-containing rock-forming minerals like olivine and pyroxene [16]. Both native Fe and $\mathrm{Ni}$ as well as alloys of the two elements are very effective in converting $\mathrm{NO}_{2}^{-}$and $\mathrm{NO}_{3}$ - into $\mathrm{NH}_{4}{ }^{+}$at $200^{\circ} \mathrm{C}$. However, at $70^{\circ} \mathrm{C}$ native $\mathrm{Ni}$ and Fe still effectively convert $\mathrm{NO}_{2}{ }^{-}$and $\mathrm{NO}_{3}{ }^{-}$into $\mathrm{NH}_{4}{ }^{+}$, whereas the reduction in the presence of FeNi alloys was insignificant [16]. During weathering of olivine and pyroxene in mafic rocks $\mathrm{Fe}(\mathrm{OH})_{2}$ may be formed as an intermediate phase in the partial oxidation of $\mathrm{Fe}(\mathrm{II})$ [18]. $\mathrm{Fe}(\mathrm{OH})_{2}$ is metastable with respect to magnetite and will convert to magnetite via a spontaneous reaction [19]. However, this conversion also creates a small amount of native iron that may assist in the reduction of $\mathrm{NO}_{2}^{-}$and $\mathrm{NO}_{3}{ }^{-}$to $\mathrm{NH}_{4}{ }^{+}$. Dekov [20] has found tiny metallic particles consisting of $\mathrm{Ni}^{0}$ in the hydrothermal sediments of the Trans-Atlantic Geotraverse (TAG) hydrothermal field, Mid-Atlantic Ridge. Oxidation-reduction processes involving simple $\mathrm{C}$ and $\mathrm{N}$ compounds in different parts oceanic crust and upper mantle have been summarized in figure 4 .

\section{Ammonium adsorption on layer silicates and zeolites}

Many layer silicates, like smectites, and zeolites have high cation exchange capacity (CEC). The CEC of minerals is generally determined in the laboratory by the uptake and release of ammonium ions $\left(\mathrm{NH}_{4}^{+}\right)$of a $1 \mathrm{M}$ ammonium acetate solution [21]. The CEC of zeolites like phillipsite is higher than that of smectite $(450 \mathrm{mEq} / 100 \mathrm{~g}$ as compared to $60-150 \mathrm{mEq} / 100 \mathrm{~g})[21,22] . \mathrm{NH}_{4}{ }^{+}$may replace $\mathrm{K}^{+}$in silicates in hydrothermal environments and eventually form ammonium feldspar, buddingtonite [23].

\section{Zeolites as catalysts for the synthesis of organic nitrogen compounds}

The adsorption properties of zeolites are very powerful, and particularly molecules with dipolar moments such as $\mathrm{H}_{2} \mathrm{O}, \mathrm{NH}_{3}, \mathrm{CO}$ and $\mathrm{HCN}$ are particularly strongly adsorbed [24,25]. CO or formate, a hydrated form of CO, may be formed as an intermediate during the reduction of $\mathrm{CO}_{2}$ to $\mathrm{CH}_{4}$ in the presence of native $\mathrm{Fe}$ and $\mathrm{Ni}$ [26]. In experiments at temperatures of about $250-325^{\circ} \mathrm{C}, \mathrm{CO}+$ $\mathrm{NH}_{3}$ adsorbed on zeolites react to give $\mathrm{HCN}$ [24]. In the same experiments, several amino acids and the puric substance adenine have been found. Shapiro [27] has dis- 


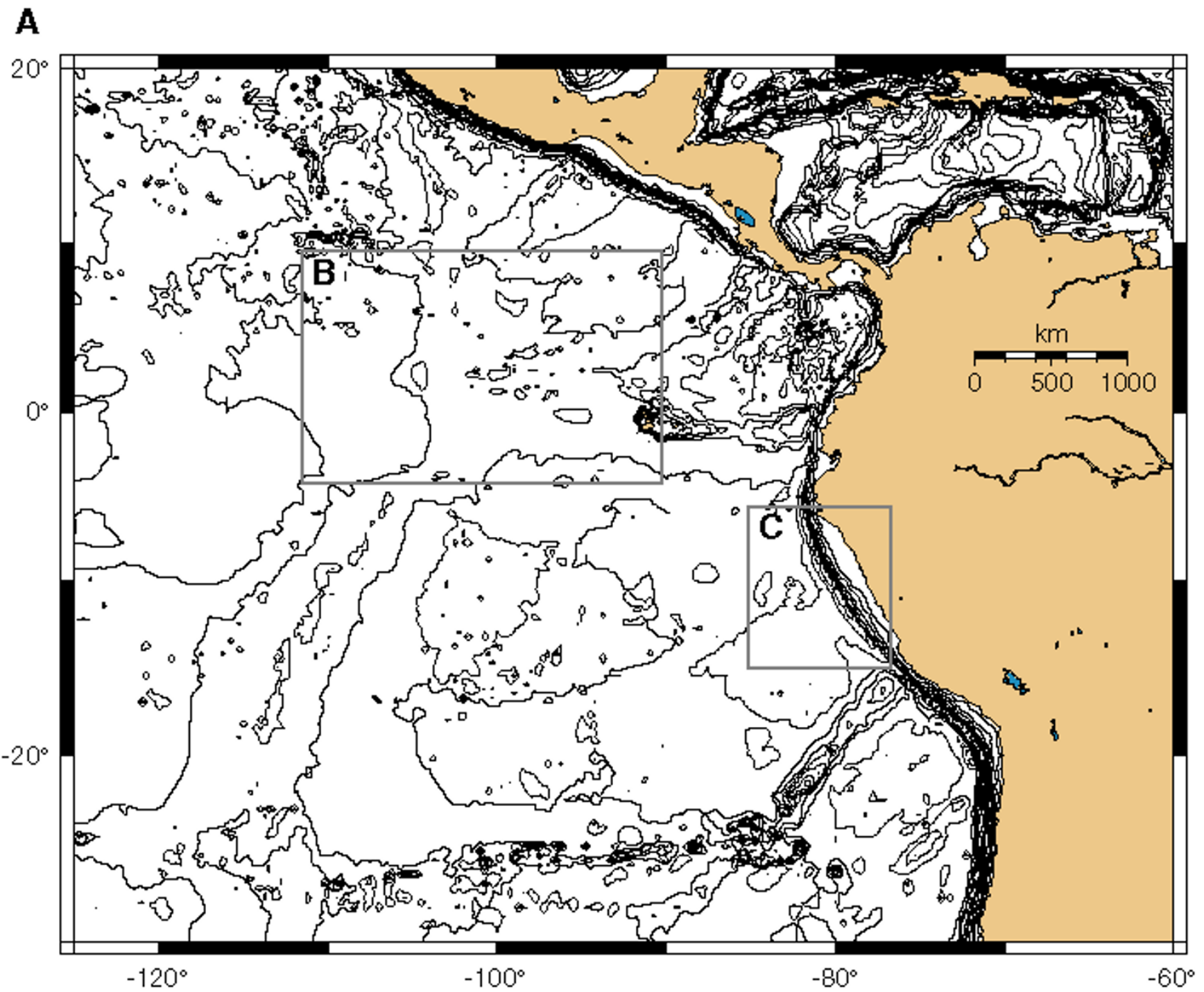

Figure I

Map showing the general areas of drill sites on both sides of the East Pacific Rise during Ocean Drilling Program (ODP) Leg 20 I in the eastern equatorial Pacific Ocean (from D'Hondt et al., 2003 [I3], used with permission of the Integrated Ocean Drilling Program (IODP)).

cussed problems in the prebiotic synthesis of adenine from $\mathrm{HCN}$ and popular ideas that adenine was easily formed and readily available on the early Earth. The background is that the purine coding elements of RNA, adenine in particular, can be easily synthesized by a one-step process from HCN $[28,29]$. One of Shapiro's [27] arguments against the availability of adenine on the early Earth is its hydrolysis at raised temperatures. For instance, according to experimental studies the half-life through nonenzymatic deaminination of adenine at $85^{\circ} \mathrm{C}$ would be 1.7 years [30]. However, most biochemical experiments trying to determine the thermal stability of organic compounds differ from traditional hydrothermal experiments in the sense that no attempts are made to control or measure important chemical or physical parameters such as oxidation state, $\mathrm{pH}$, fugacities of dissolved gas species, or major and trace element compositions of the experimental systems [31]. As a comparison, recent geochemical studies have shown that adenine remains in detectable concentrations still after 200 hours at $300^{\circ} \mathrm{C}$ under fugacities of $\mathrm{CO}_{2}, \mathrm{~N}_{2}$ and $\mathrm{H}_{2}$ representative of those in hydrothermal systems of the early Earth [32]. Another important feature of hydrothermal cells is that they are dynamic flow through systems. An organic compound 

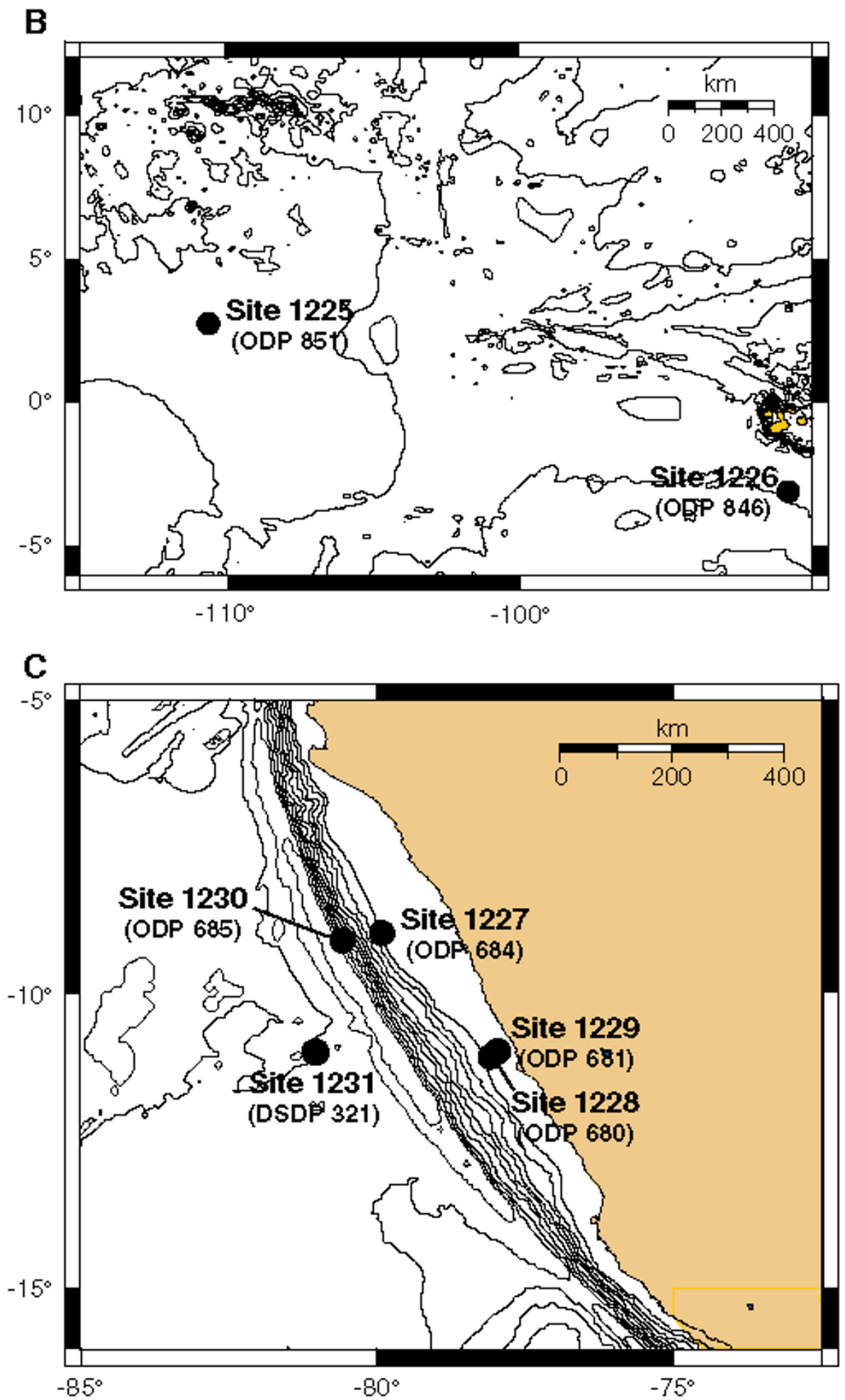

Figure 2

Details of figure I. Previous DSDP/ODP site designations are in parantheses. The nitrate concentration of the sediment pore water of Site I 225 and Site I 23 I are shown in figure 3. Site I 225 is located W of the East Pacific Rise spreading center and Site I23I W of the subduction zone of the Peru margin (from D'Hondt et al., 2003 [13], used with permission of IODP). 

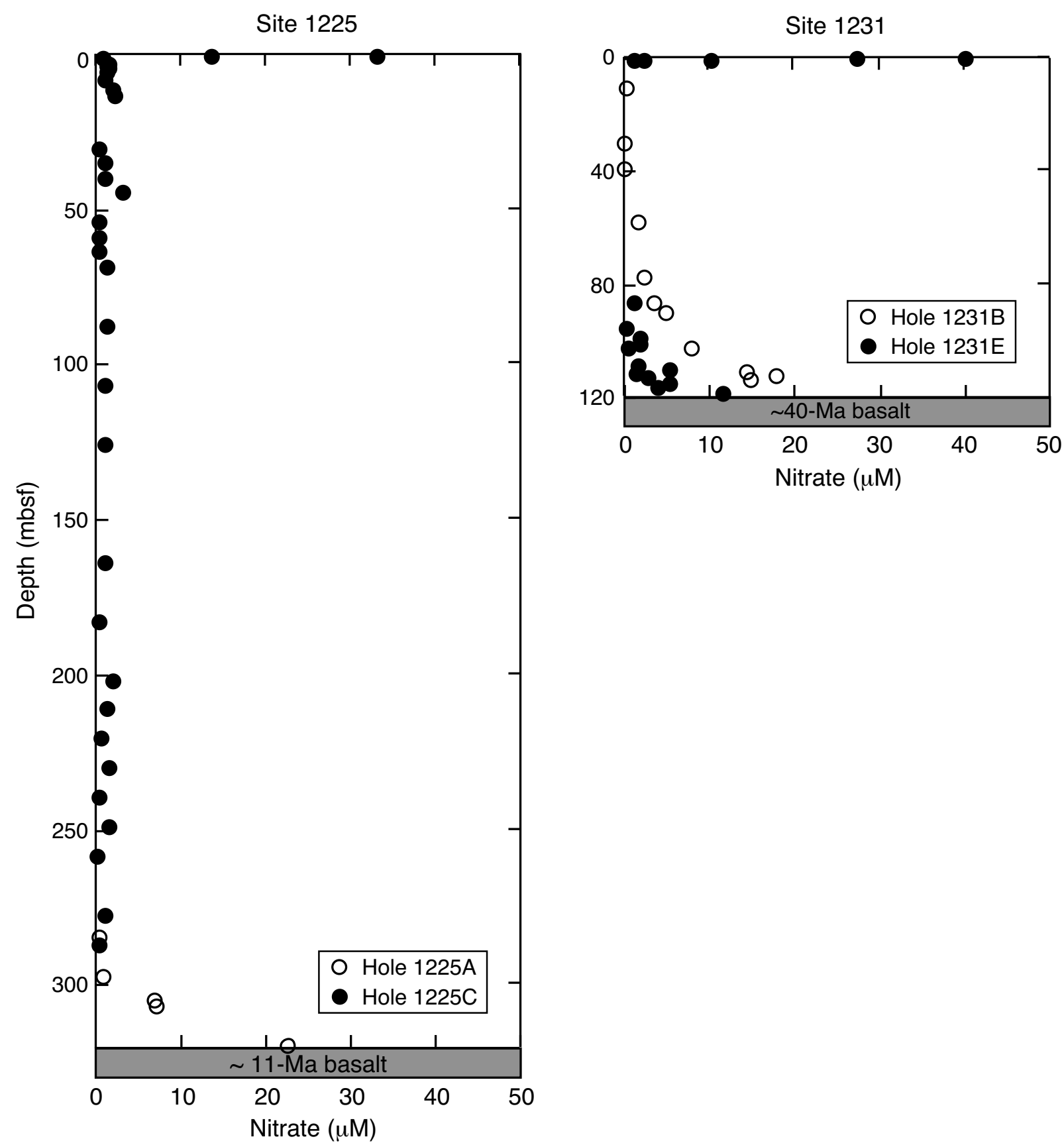

Figure 3

Dissolved nitrate concentration in sediment pore fluids at open-ocean ODP Sites I 225 and I 23 I. The nitrate values show that fresh seawater is channeled upwards into deep-sea sediments via the rocks underneath (from D'Hondt et al., 2003 [I3], used with permission of IODP). 

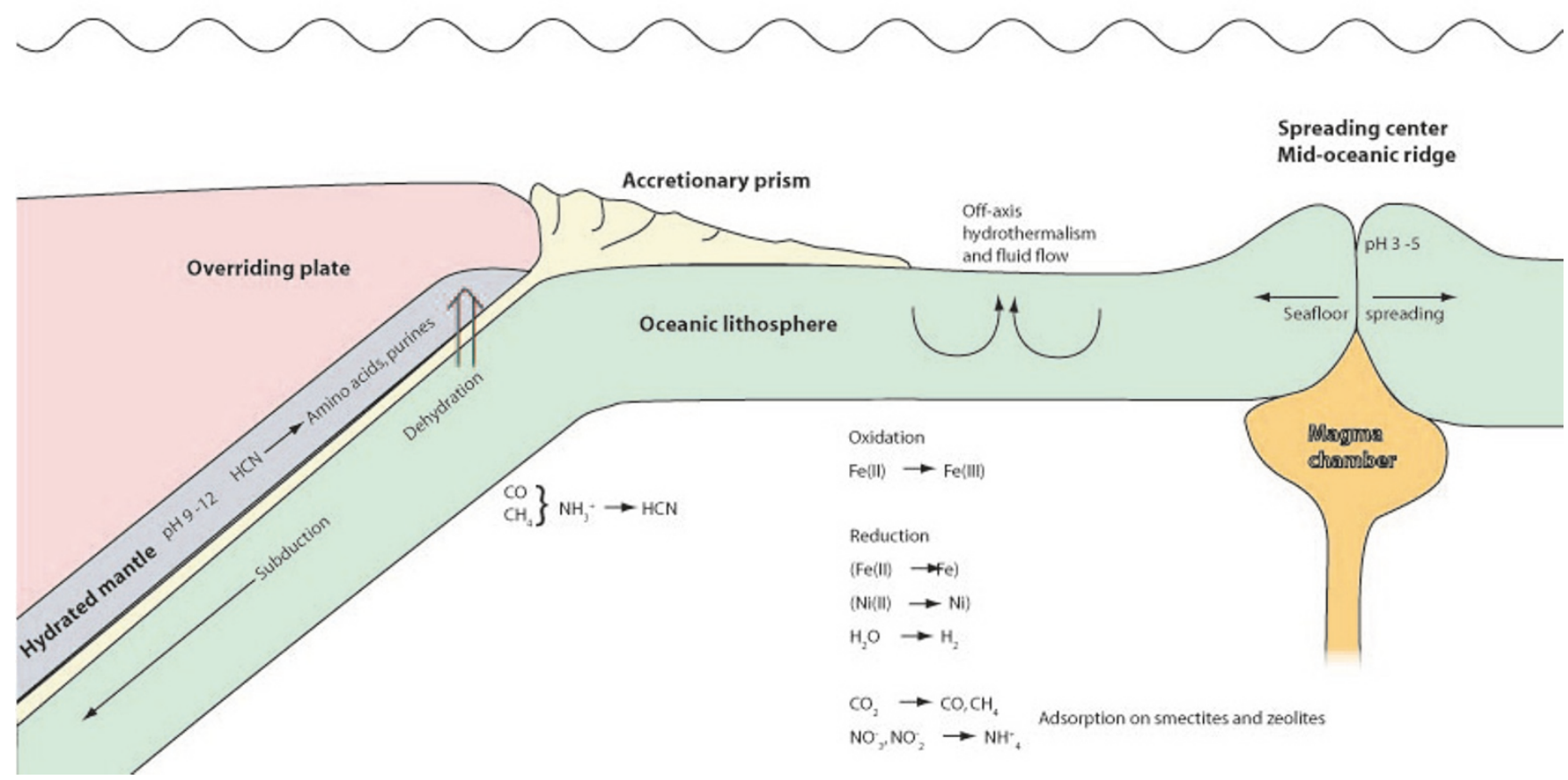

Figure 4

Cartoon showing a cross section of oceanic lithosphere, extending from the spreading center to the subduction zone. Off-axis hydrothermal flow in the oceanic lithosphere causes oxidation of Fe(II) to Fe(III) and reduction of water to molecular hydrogen. Some $\mathrm{Fe}(\mathrm{II})$ and $\mathrm{Ni}(\mathrm{II})$ is reduced to native metals. Carbon dioxide is reduced to carbon monoxide and methane, while nitrate and nitrite may be reduced to ammonium and adsorbed on smectites and zeolites. During early subduction the descending plate is heated and dehydrated. Adsorbed carbon monoxide and methane may react with ammonia and form hydrogen cyanide. The released fluid carrying hydrogen cyanide rises from an environment of relatively low $\mathrm{pH}$ into hydrated mantle rock of high $\mathrm{pH}$. At the high $\mathrm{pH}$ hydrogen cyanide may form HCN oligomers as well as amino acids, purine bases, nucleosides and, perhaps, nucleotides.

that has been synthesized at high temperature will not necessarily remain within that environment for a long time.

One additional argument by Shapiro [27] against abiotic adenine formation on the young Earth was that such synthesis would require HCN concentrations of at least 0.01 M. Such concentrations in fluids would have been expected only under unique circumstances on the early Earth. However, since HCN is strongly adsorbed by zeolites it could be much more concentrated on surfaces than in solution. As an example, the adsorption properties of zeolites are so powerful that a $10^{-4} \mathrm{~atm}$ partial pressure of $\mathrm{CH}_{4}$ suffices to fill up the zeolites cavities entirely with physically adsorbed molecules at liquid air temperature [24]. Since molecules with dipolar moments are still more strongly adsorbed, even lower activities of those would be necessary. In addition, $\mathrm{HCN}$ will outcompete $\mathrm{H}_{2} \mathrm{O}$ on the zeolite surfaces due to higher dipole moment [33].

\section{The importance of $\mathrm{HCN}$}

Hydrogen cyanide is central to most of the reaction pathways leading to abiotic formation of simple organic compounds containing nitrogen. HCN is likely to have been present in prebiotic hydrothermal environments because it is formed by a variety of processes driven by thermal energy [34]. HCN is, for instance, readily formed by reactions such as

$$
\begin{gathered}
2 \mathrm{CH}_{4}+\mathrm{N}_{2} \rightarrow 2 \mathrm{HCN}+3 \mathrm{H}_{2} \\
\mathrm{CO}+\mathrm{NH}_{3} \rightarrow \mathrm{HCN}+\mathrm{H}_{2} \mathrm{O}
\end{gathered}
$$

These reactions are promoted by heat (geothermal), UV light, or electric discharges (lightning) [35]. Since the conversion of $\mathrm{N}_{2}$ to $\mathrm{NH}_{3}$ is relatively sluggish in off-axis type hydrothermal environments [16], pathway no. 2 is perhaps more likely to occur in mafic rocks than pathway no. 1. On the other hand, an additional possibility would be formation of $\mathrm{HCN}$ from $\mathrm{CH}_{4}$ and $\mathrm{NH}_{3}$, which is known to occur in the presence of aluminum oxide and silicate at high temperatures [36,37]: 


$$
\mathrm{CH}_{4}+\mathrm{NH}_{3} \rightarrow \mathrm{HCN}+3 \mathrm{H}_{2}
$$

Shock [38] has calculated the concentrations of HCN from $\mathrm{CO}_{2}$ and $\mathrm{N}_{2}$ along paths in East-Pacific Rise type onaxis and off-axis hydrothermal systems. The initial fugacities of $\mathrm{CO}_{2}$ and $\mathrm{N}_{2}$ were set to 10 bars and 1 bar, respectively. In both cases the maximum concentration would be $10^{-10}-10^{-11} \mathrm{M} \mathrm{HCN}$ in an environment buffered by the fayalite-magnetite-quartz (FMQ) mineral buffer assemblage at temperatures of $250-400^{\circ} \mathrm{C}$. Obviously, this would not be optimal conditions for HCN formation. However, recently LaRowe and Regnier [39] calculated the thermodynamic potential for the abiotic synthesis in hydrothermal systems of the RNA and DNA purine and pyrimidine bases as well as ribose and deoxyribose. The activities of precursor molecules (formaldehyde and hydrogen cyanide) required to evaluate the thermodynamics of biomolecule synthesis were computed using the concentrations of aqueous $\mathrm{N}_{2}, \mathrm{CO}, \mathrm{CO}_{2}$, and $\mathrm{H}_{2}$ reported in the ultramafic Rainbow hydrothermal system on the Mid-Atlantic Ridge. Their results suggest that nucleobases at activities of $10^{-2}-10^{-6} \mathrm{M}$ can be in equilibrium with a range of precursor molecule activities at $150^{\circ} \mathrm{C}$ and 500 bars, i.e. approximately under the conditions of hydrothermal flanks.

In order to participate in abiotic organic reactions $\mathrm{HCN}$ must first be concentrated. In addition to adsorption on mineral surfaces, one possibility is concentration to a reservoir of ferrocyanide at relatively low $\mathrm{pH}$ from which free $\mathrm{HCN}$ can be released upon local elevation of the $\mathrm{pH}$ $[1,40]$. HCN reacts with ferrous ions to give ferrocyanide, provided that the concentration of hydrogen sulphide is low [41]. The elevation of $\mathrm{pH}$ would lead to oxidation of $\mathrm{Fe}(\mathrm{II})$ and precipitation of the iron as $\mathrm{FeOOH}$. This would avoid the 'Miller paradox', which refers to the side reaction of glycolonitrile (cyanohydrin of formaldehyde) formation from free HCN and ubiquitous formaldehyde [42]. Formaldehyde and HCN, if present in the same environment, tends to react to form stable glyconitrile. In natural environments, the occurrence of ferrocyanides in hydrothermal environments has been reported from the Kuril Islands and the Kamchatka Peninsula $[43,44]$.

The self condensation of HCN in mildly basic solutions results in the formation of the tetramer diaminomaleonitrile (DAMN), which is a central intermediate in the formation of the purine ring and HCN oligomers [34]. Purines, especially adenine, are easy to form abiotically. Purines may be formed from HCN via two routes: one route is via $\mathrm{HCN}$ oligomers (that may also form amino acids); the second is via DAMN directly $[45,46]$. The abiotic formation of pyrimidines is much more problematic, very little pyrimidines have, for instance, been reported from carbonaceous chondrites [47]. It is known that double layer hydroxides promote the adsorption of cyanide and its self-addition to DAMN even down to low cyanide concentrations $(0.01 \mathrm{M})[6]$. The purine coding elements of nucleic acids are also much more strongly adsorbed to solids than the pyrimidines [48,49].

\section{Serpentinization of olivine}

Olivine is one of the most easily weathered $\mathrm{Fe}(\mathrm{II})$ minerals and is particularly common in ultramafic rocks. Alteration of olivine in contact with water during hydrothermal circulation leads to 'serpentinization', a process in which $\mathrm{Fe}(\mathrm{II})$ in olivine in a side reaction is oxidized to $\mathrm{Fe}(\mathrm{III})$ coupled to reduction of water [50]. The entire process leads to the formation of serpentine, magnetite, molecular hydrogen and - during serpentinization at low temperature (less than about $315^{\circ} \mathrm{C}$ ) - brucite $[51,52]$. Due to the formation of molecular hydrogen serpentinized ultramafic rocks are important environments for chemoautotrophic bacteria on the modern Earth. Brucite incorporates an increasing amount of $\mathrm{Fe}(\mathrm{II})$ with decreasing temperature, so the amount of Fe converted to magnetite (and $\mathrm{H}_{2} \mathrm{O}$ to $\mathrm{H}_{2}$ ) decreases with decreasing temperature below $315^{\circ} \mathrm{C}[52,53]$ :

$\underset{\text { olivine }}{2 \mathrm{Mg}_{1.8} \mathrm{Fe}_{0.2} \mathrm{SiO}_{4}}+\underset{\mathrm{H}_{2} \mathrm{O}}{3} \rightarrow \underset{\text { serpentine }}{\mathrm{Mg}_{2.85} \mathrm{Fe}_{0.15} \mathrm{Si}_{2} \mathrm{O}_{5}(\mathrm{OH})_{4}}+\underset{\text { ferrobrucite }}{\mathrm{Mg}_{0.75} \mathrm{Fe}_{0.25}(\mathrm{OH})_{2}}$

However, the stability of Fe-rich brucite depends on the activity of $\mathrm{H}_{2}$ in the system and, if the $\mathrm{H}_{2}$ activity decreases, Fe-bearing brucite will become unstable, decomposing to magnetite and brucite with a lower Fe content [52]:

$$
\underset{\text { ferrobrucite }}{12 \mathrm{Mg}_{0.75} \mathrm{Fe}_{0.25}}(\mathrm{OH})_{2} \square \underset{\text { magnetite }}{\mathrm{Fe}_{3} \mathrm{O}_{4}}+\underset{\text { brucite }}{9 \mathrm{Mg}(\mathrm{OH})_{2}}+\underset{\text { hydrogen }}{\mathrm{H}_{2}}+\underset{2 \mathrm{H}_{2} \mathrm{O}}{9}
$$

Therefore, in serpentinites initially formed at low temperatures, the destabilization of Fe-bearing brucite may result in a steady source of $\mathrm{H}_{2}$ in response to loss of $\mathrm{H}_{2}$ from the system [52]. A characteristic feature of many serpentinization systems is the high fluid $\mathrm{pH}$, ranging up to values of about 12.6, because of the high solubility of the brucite [51]. Alkaline fluids are characteristic of deep aquifers of ultramafic rocks such as hydrothermal systems of ridge flanks (Lost City, Mid-Atlantic Ridge; pH 9-9.8 [11]) and non-accretionary supra-subduction zones (SSZ) (Mariana forearc; $\mathrm{pH} 12.6$ [54]). By comparison, the measured values of $\mathrm{pH}$ for basaltic vent fluids at $25^{\circ} \mathrm{C}$ and 1 bar are in the range 3 to 4 for fluids venting from sediment starved ridge crests [38].

\section{Methane in layer silicates}

Methane-rich plumes in deep ocean waters are known to be linked to hydrothermal circulation [55]. Fischer-Trop- 
sch type (FTT) reactions are well known processes for converting $\mathrm{CO}_{2}$ to hydrocarbons (primarily $\mathrm{CH}_{4}$ ) by reaction with $\mathrm{H}_{2}$ and takes place on a large scale around mid-oceanic ridges $[18,55]$. Hydrocarbon generation through FTT is only possible if $\mathrm{H}_{2}$ is first generated. Production of molecular hydrogen in oceanic lithosphere is normally a result of serpentinization. It is well known that it is difficult to produce organic molecules directly from $\mathrm{CO}_{2}$ in abiotic synthesis experiments [18]. It is, however, easy to do it from $\mathrm{CO}$ and commercial Fischer-Tropsch reactions are normally optimized for the synthesis of hydrocarbons from $\mathrm{CO}$ and $\mathrm{H}_{2}[34]$. It is likely that native metals present in mafic rock like Fe and $\mathrm{Ni}$ and $\mathrm{FeNi}$ alloys reduce $\mathrm{CO}_{2}$ to $\mathrm{CO}$ or formate as an intermediate in abiotic organic synthesis [18].

It has been found that treatment with strong alkali releases methane, in particular, but also ethane and propane from both oxidized and reduced sediments $[13,56]$. The hydrocarbons could, in principle, have been formed either abiotically or biologically. The requirement to use strong base suggests that they are strongly sorbed to hydrophobic siloxane patches of the tetrahedral layer within the interlayer region of minerals like smectites $[57,58]$. Hydrocarbons that are formed abiotically on the flanks of mid-oceanic ridges will be adsorbed strongly on such secondary layer minerals. Once adsorbed, they will be carried passively along with the oceanic plate towards a subduction zone. Even though $\mathrm{CH}_{4}$ and $\mathrm{NH}_{3}$ (and probably $\mathrm{HCN}$ ) will exist adsorbed on secondary minerals close to each other not much will happen with regard to organic chemistry until the initial phase of subduction of the plate starts. Thus, oceanic plates become conveyor belts of organic precursors from spreading centers to subduction zones.

\section{Organic processes during subduction of plates}

Convergent margins in the form of subduction zones are the most dynamic regions on Earth. As the plate descends, fluids distilled from the plate influence and even control fundamental processes in the subduction zone (figure 4). The subducting plate, along with its fluids and altered igneous rock (and often sediments), interact with the overriding plate along the subduction zone. Fluids originating in the subducting plate will rise through the upper plate with its hydrated ultramafic mantle material (e.g. brucite) in the lower parts. The fluids may thus move from a relatively acidic environment in basalt altered to palagonite into an alkaline environment in serpentinized peridotite. The high $\mathrm{pH}$ promotes formation of, for instance, carbohydrates like ribose from simple organic compounds. It also supports the synthesis of amino acids and purine nitrogen bases as well as their condensation to nucleotides in the presence of phosphorylated ribose [59] (see 'Prebiotic implications of subduction' below).
Hydrothermal fluid circulation in subducting basement also redistributes and extracts heat from the subduction zone, lowering temperatures far into the system and raising temperatures in the shallow subduction zone [60].

The Mariana forearc in the western Pacific Ocean is a nonaccretionary forearc with numerous seamounts next to a deep ocean trench [61]. Secondary minerals at the South Chamorro Seamount include serpentine group minerals, brucite and magnetite [62]. The brucite of the South Chamorro Seamount serpentinites is never a pure $\mathrm{Mg}(\mathrm{OH})_{2}$, but always contains a significant amount of $\mathrm{Fe}(\mathrm{OH})_{2}$, thus indicating serpentinization well below $315^{\circ} \mathrm{C}[9,52,53]$. The existence of $\mathrm{Fe}(\mathrm{OH})_{2}$ is of particular interest to prebiotic chemistry both because of the potential formation of native $\mathrm{Fe}$ and maintenance of low redox conditions (see section 'Nitrogen reduction in oceanic basement'), as well as increased stability of pyrophosphate in the presence of $\mathrm{Fe}(\mathrm{II})$ [63]. Chemical energy stored in pyrophosphates could have been used by primitive forms of life on the early Earth or for abiotic phosphorylation of carbohydrates and nucleosides [64].

The upper temperature limit for serpentinization at the Mariana forearc has been estimated to $\sim 200-300^{\circ} \mathrm{C}$ [62]. Interstitial fluids of $\mathrm{pH} 12.6$ associated with serpentinized mud at the South Chamorro seamount are enriched in dissolved carbonate, light hydrocarbons, ammonia and borate [54]. The interstitial fluids are, however, depleted in chlorinity as compared to seawater, which indicates a slab source of the fluids [61], probably due to smectite-toillite transformation $[58,65]$. Pore fluids from Conical Seamount contain light hydrocarbons as well as organic acids, while fluid inclusions of the associated carbonate chimneys show the presence of light as well as longer chain hydrocarbons, aromatics and acetate [66]. These fluids derive from the subducting Pacific plate at an early stage of dehydration. After the fluids have been expelled from the subducting plate at moderate temperatures they are cooled down to a few ${ }^{\circ} \mathrm{C}$ on passage through the overriding Philippines plate/Mariana forearc.

Russell and coworkers have in a number of articles (see, for instance, Russell et al., 2005 [67]) proposed that modulated interactions between alkaline hydrothermal solutions and a weakly acidic early ocean created the conditions suitable for the reduction of $\mathrm{CO}_{2}$ to organic molecules and the onset of life. In the light of such ideas, a subduction zone setting like the Mariana forearc is optimal. Fluids would be distilled and squeezed out of secondary minerals into a relatively acidic environment (basalt/palagonite) (figure 4). $\mathrm{CH}_{4}$ and $\mathrm{NH}_{4}{ }^{+}$inherent in the fluids will react upon heating during subduction and form HCN. The fluids then rise through a strongly alkaline environment (serpentinized peridotite) into deep 
ocean water of, again, lower $\mathrm{pH}$. Upon the increase of $\mathrm{pH}$ in hydrated mantle rocks, dissolved $\mathrm{Fe}(\mathrm{II})$ in ferrocyanide would be oxidized and precipitate as $\mathrm{FeOOH}$. $\mathrm{CN}^{-}$is, therefore, released and ready to participate in organic reactions. In his article, Shapiro [27] remarked that the rate of abiotic adenine formation from $\mathrm{HCN}$ is maximal at $\mathrm{pH} 9.2$, which he, at the time, considered unlikely for environments of global distribution on the early Earth. In addition to adenine, amino acids may be synthesized in hydrothermal environments at fairly low temperatures $\left(150^{\circ} \mathrm{C}\right)$ by Strecker type reactions (synthesis of amino acids from cyanide and aldehyde in the presence of ammonia) [68].

\section{Further prebiotic implications of the subduction}

Pentoses like ribose can be formed by the formose reaction under alkaline conditions from simple organic precursors (formaldehyde and glycolaldehyde) [45,46]. Ribose is, like adenine, a major constituent of RNA. The formation of ribose proceeds by the stepwise condensation of formaldehyde to a dimer (glycolaldehyde), trimer, etc. Aldehydes can be formed directly from elemental carbon in the presence of water [69]. Elemental carbon in the form of graphite is common in peridotites [70]. The initial reaction of elemental carbon with water gives hydroxymethylene, which can rearrange to formaldehyde. A new hydroxymethylene molecule can then add onto the formaldehyde (and larger aldehyde molecules) and form glycolaldehyde. For a while, the formose reaction has been an outdated concept in prebiotic chemistry. A major reason for this is that the reaction proceeds at a constructive rate only under what was stated as naturally 'improbable' conditions, i.e. under highly alkaline conditions [9]. The recent discovery of alkaline hydrothermal systems in ultramafic settings, like the Mariana forearc, indicates that alkaline environments may be much more common on Earth than we thought just a few years ago. It has also been shown that borate minerals stabilize pentoses, particularly ribose $[9,71,72]$. The stability of the ribose-boron complex increases with increasing $\mathrm{pH}$.

Even though a $\mathrm{pH}$ increase will destroy siloxane bonds between silicate minerals and methane, this is probably not the mechanism responsible for the release of methane and larger hydrocarbons in subduction zones. $\mathrm{CH}_{4}$ and $\mathrm{NH}_{4}{ }^{+}$bound to secondary minerals in the basaltic layer of the subducting plate will not experience the $\mathrm{pH}$ increase of the hydrated mantle of the overriding plate until they are already expelled from secondary minerals. Distillation, compaction, smectite-to-illite transition and similar diagenetic reactions are likely to be responsible for the liberation of the organic precursors $[58,65]$. However, even though conditions for abiotic organic synthesis may prevail in these environments, much of the organic precursors will pass relatively unaltered through the 'subduction factory' due to lack of activation energy, which is shown by the high concentrations of light hydrocarbons and ammonia in the Mariana forearc fluids [53]. Still, the possibility exists that the formose reaction is responsible for abiotic formation of ribose in natural settings and that this may occur in close vicinity to purine synthesis and, perhaps, phosphorylation processes [9]. The potential of pyro- and trimetaphosphate formation in hydrothermal environments of convergent margins has never really been evaluated. Once such condensed phosphates are available, phosphorylation of ribose or purine nucleosides is possible.

\section{Conclusion}

- Nitrate and nitrite may be reduced to ammonium in oceanic basement in the presence on native $\mathrm{Fe}$ or $\mathrm{Ni}$.

- The reduction is most efficient in hydrothermal environments.

- Ammonium may form hydrogen cyanide with carbon monoxide or methane.

- Hydrogen cyanide is an excellent starting compound for abiotic organic reactions.

- Oceanic plates are conveyor belts to the subduction zones of organic precursors formed in hydrothermal environments off-axis.

- The most potent prebiotic organic reactions on Earth occur in mafic rocks that are in the initial phase of subduction.

- The origin of life was, perhaps, only possible on planets with some kind of plate tectonics

\section{Competing interests}

The authors declare that they have no competing interests.

\section{Authors' contributions}

$\mathrm{NH}$ outlined the general structure of the paper and wrote the manuscript. AN provided the discussion on serpentinization of olivine and designed the cartoon in figure 4 . Both authors have contributed to the discussion on prebiotic implications of subduction as well as read and approved the final manuscript.

\section{Acknowledgements}

This research has been supported by the Swedish Research Council.

\section{References}

I. Arrhenius GO: Crystals and life. Helv Chim Acta 2003, 86: $1569-1586$.

2. Honma $\mathrm{H}$ : High ammonium contents in the $\mathbf{3 8 0 0} \mathrm{Ma}$ Isua supracrustal rocks, central West Greenland. Geochim Cosmochim Acta 1996, 60:2 173-2178. 
3. Ward PD, Brownlee D: Rare Earth: Why complex life is uncommon in the Universe New York, Copernicus; 2000.

4. Schiffman P, Southard RJ: Cation exchange capacity of layer silicates and palagonitized glass in mafic volcanic rocks: A comparative study of bulk extraction and in situ techniques. Clays Clay Miner 1996, 44:624-634.

5. Alt JC: Subseafloor processes in mid-ocean ridge hydrothermal systems. In Seafloor hydrothermal systems Edited by: Humphris SE, Zierenberg RA, Mullineaux LS. Thomson. Washington, DC, American Geophysical Union; 1995:85-II4

6. Boclair JW, Braterman PS, Brister BD, Jiang J, Lou S, Wang Z, Yarberry F: Cyanide self-addition, controlled adsorption, and other processes at layered double hydroxides. Origins Life Evol Biosphere 200I, 31:53-69.

7. Kastner M: Zeolites. In Marine minerals Edited by: Burns RG. Washington, DC, Mineralogical Society of America; 1979:I I I-I 22.

8. Allman R: Doppelschichtstrukturen mit brucitähnlichen Schichtionen $\left[\mathrm{Me}(\mathrm{II})_{1-x} \mathrm{Me}(\mathrm{III})_{\mathbf{x}}(\mathrm{OH})_{2}\right]^{\mathrm{x}+}$. Chimia 1970, 24:99-108.

9. Holm NG, Dumont M, Ivarsson M, Konn C: Alkaline fluid circulation in ultramafic rocks and formation of nucleotide constituents: A hypothesis. Geochem T 2006, 7:7.

10. Fehn $U$, Cathles LM: The influence of plate movement on the evolution of hydrothermal convection cells in the oceanic crust. Tectonophysics 1986, 125:289-3/2.

1 I. Kelley DS, Karson JA, Blackman DK, Früh-Green GL, Butterfield DA Lilley MD, Olson EJ, Schrenk MO, Roe KK, Lebon GT, Rivizzogni P, AT3-60 Shipboard Party: An off-axis hydrothermal vent field near the Mid-Atlantic Ridge at $30^{\circ} \mathrm{N}$. Nature 200 I, 4I 2: I 45- I 49.

12. Kelley DS, Karson JA, Früh-Green GL, Yoerger DR, Shank TM, Butterfield DA, Hayes JM, Schrenk MO, Olson El, Proskurowski G, Jakuba GM, Bradley A, Larson B, Ludwig K, Glickson D, Buckman K, Bradley AS, Brazelton WJ, Roe K, Elend MJ, Delacour A, Bernascon SM, Lilley MD, Baross JA, Summons RE, Sylva SP: A serpentinitehosted ecosystem: The Lost City hydrothermal field. Science 2005, 307: I 428-1434.

13. D'Hondt SL, Jørgensen BB, Miller DJ, Aiello IW, Bekins B, Blake R, Cragg BA, Cypionka H, Dickens GR, Ferdelman T, Ford K, Gettemy GL, Guèrin G, Hinrichs K-U, Holm NG, House C, Inagaki F, Meister P, Mitterer RM, Naehr T, Niitsuma S, Parkes RJ, Schippers A, Skilbeck CG, Smith DC, Spivack AJ, Teske A, Wiegel J, Naranjo Padilla C, Solis Acosta JS: Controls on Microbial Communities in Deeply Buried Sediments, Eastern Equatorial Pacific and Peru Margin. Proceedings of the Ocean Drilling Program, Initial Reports 201 College Station: Ocean Drilling Program; 2003.

14. D'Hondt S, Jørgensen BB, Miller DJ, Batzke A, Blake R, Cragg BA Cypionka H, Dickens GR, Ferdelman T, Hinrichs K-U, Holm NG, Mitterer R, Spivack A, Wang G, Bekins B, Engelen B, Ford K, Gettemy G, Rutherford SD, Sass H, Skilbeck CG, Aiello IW, Guèrin G, House CH, Inagaki $F$, Meister $P$, Naehr T, Niitsuma $S$, Parkes RJ, Schippers A Smith DC, Teske A, Wiegel J, Naranjo Padilla C, Solis Acosta JL: Distributions of microbial activities in deep subseafloor sediments. Science 2004, 306:2216-2221.

15. Bekins BA, Spivack AJ, Davis EE, Mayer LA: Dissolution of biogenic ooze over basement edifices in the equatorial Pacific with implications for hydrothermal ventilation of the oceanic crust. Geology 2007, 35:679-682.

16. Smirnov A, Hausner D, Laffers R, Strongin DR, Schoonen MAA: Abiotic ammonium formation in the presence of $\mathrm{Ni}$-Fe metals and alloys and its implications for the Hadean nitrogen cycle. Geochem T 2008, 9:5.

17. Brandes JA, Boctor NZ, Cody GD, Cooper BA, Hazen RM, Yoder HS Jr: Abiotic nitrogen reduction on the early Earth. Nature 1998, 395:365-367.

18. Holm NG, Charlou JL: Initial indications of abiotic formation of hydrocarbons in the Rainbow ultramafic hydrothermal system, Mid-Atlantic Ridge. Earth Planet Sci Lett 200 I, 191:I-8.

19. Schoonen M, Smirnov A, Cohn C: A perspective on the role of minerals in prebiotic synthesis. Ambio 2004, 33:539-55I.

20. Dekov $\mathrm{V}$ : Native nickel in the TAG hydrothermal field sediments (Mid-Atlantic Ridge, $26^{\circ} \mathrm{N}$ ): Space trotter, guest from mantle, or a widespread mineral, connected with serpentinization? J Geophys Res 2006, I I I:B05 103.

21. Eby GE: Environmental geochemistry Pacific Grove, CA: Brooks/ColeThomson; 2004.
22. Brownlow AH: Geochemistry Upper Saddle River, NJ: Prentice-Hall; 1996.

23. Erd RC, White DE, Fahey J], Lee DE: Buddingtonite, an ammonium feldspar with zeolitic water. Am Mineral I964, 49:83 I-850.

24. Fripiat JJ, Poncelet G, van Assche AT, Mayaudon J: Zeolite as catalysts for the synthesis of amino acids and purines. Clays Clay Miner 1972, 20:331-339.

25. Gualtieri AF: Study of $\mathrm{NH}_{4}{ }^{+}$in the zeolite phillipsite by combined synchrotron powder diffraction and IR spectroscopy. Acta Chrystallogr 2000, B56:584-593.

26. Horita J, Berndt : Abiogenic methane formation and isotopic fractionation under hydrothermal conditions. Science 1999, 285: 1055-1057.

27. Shapiro R: The prebiotic role of adenine: A critical analysis. Origins Life Evol Biosphere 1995, 25:83-98.

28. Oró J: Synthesis of adenine from hydrogen cyanide. Biochem Biophys Res Commun 1960, 2:407-4I2.

29. Oró J: Mechanisms of synthesis of adenine from hydrogen cyanide under possible primitive Earth conditions. Nature |961, 191: | | $93-1 \mid 94$.

30. Frick L, MacNeela JP, Wolfenden R: Transition state stabilization by deaminases: Rates of nonenzymatic hydrolysis of adenosine and cytidine. Bioorg Chem 1987, I 5:100-108.

3I. Holm NG, Andersson E: Hydrothermal simulation experiments as a tool for studies of the origin of life on Earth and other terrestrial planets: A review. Astrobiology 2005, 5:444-460.

32. Franiatte M, Richard L, Elie M, Nguyen-Trung C, Perfetti E, LaRowe DE: Hydrothermal stability of adenine under controlled fugacities of $\mathbf{N}_{2}, \mathbf{C O}_{2}$, and $\mathbf{H}_{\mathbf{2}}$. Origins Life Evol Biospheres 2008, 38:139-148

33. Kotdawala RR, Kazantzis N, Thompson RW: Molecular simulation studies of adsorption of hydrogen cyanide and methyl ethyl ketone on zeolite $\mathrm{NaX}$ and activated carbon. J Hazard Mater 2008, 159:169-176.

34. Ferris JP: Chemical markers of prebiotic chemistry in hydrothermal systems. In Marine hydrothermal systems and the origin of life Edited by: Holm NG. Dordrecht, Kluwer; 1992:109-134.

35. Lehninger AL: Biochemistry New York: Worth; 1970.

36. Nisbet EG: RNA, hydrothermal systems, zeolites and the origin of life. Episodes 1986, 9:83-90.

37. Rauchfuss $\mathrm{H}$ : Chemical evolution and the origin of life Berlin: Springer; 2008.

38. Shock EL: Chemical environments of submarine hydrothermal systems. In Marine hydrothermal systems and the origin of life Edited by: Holm NG. Dordrecht, Kluwer; 1992:67-107.

39. LaRowe DE, Regnier P: Thermodynamic potential for the abiotic synthesis of adenine, cytocine, guanine, thymine, uracil, ribose, and deoxyribose in hydrothermal systems. Origins Life Evol Biospheres 2008, 38:383-397.

40. Arrhenius T, Arrhenius G, Paplawski W: Archean geochemistry of formaldehyde and cyanide and the oligomerization of cyanohydrin. Origins Life Evol Biosphere 1994, 24:I-17.

4I. Keefe AD, Miller SL: Was ferrocyanide a prebiotic reagent? Origins Life Evol Biosphere 1996, 26: I I-I29.

42. Schlesinger G, Miller SL: Equilibrium and kinetics of glyconitrile formation in aqueous-solution. I Am Chem Soc 1973, 95:3729-3735.

43. Mukhin LM: Evolution of organic compounds in volcanic regions. Nature 1974, 25 I:50-5I.

44. Mukhin LM, Bondarev VB, Safonova EN: The role of volcanic processes in the evolution of organic compounds on the primitive Earth. Modern Geology 1978, 6: I 19-122.

45. Ferris JP: Origins of Life. In Biochemistry Edited by: Zubay G. New York: Macmillan; 1988: | |20-1| I5I.

46. Ferris JP: Catalysis and prebiotic synthesis. Reviews in Mineralogy \& Geochemistry 2005, 59:187-210.

47. Stoks PG, Schwartz AW: Uracil in carbonaceous meteorites. Nature 1979, 282:709-710.

48. Sowerby SJ, Cohn CA, HeckI WM, Holm NG: Differential adsorption of nucleic acid bases: Relevance to the origin of life. Proc Natl Acad Sci USA 200I, 98:820-822.

49. Cohn CA, Hansson TK, Larsson HS, Sowerby SJ, Holm NG: Fate of prebiotic adenine. Astrobiology 200I, I:477-480.

50. Holm NG, Andersson EM: Organic molecules on the primitive Earth: Hydrothermal systems. In The Molecular Origins of Life: 
Assembling Pieces of the Puzzle Edited by: Brack A. Cambridge: Cambridge University Press; 1998:86-99.

51. Moody JB: Serpentinization: A review. Lithos 1976, 9:125-138.

52. McCollom TM, Bach W: Thermodynamic constraints on hydrogen generation during serpentinization of ultramafic rocks. Geochim Cosmochim Acta 2009, 73:856-875.

53. Bach W, Paulick H, Garrido CJ, Ildefonse B, Meurer WP, Humphris SE: Unraveling the sequence of serpentinization reactions: Petrography, mineral chemistry, and petrophysics of serpentinites from MAR I $5^{\circ} \mathrm{N}$ (ODP Leg 209, Site I 274). Geophys Res Lett 2006, 33:LI3306.

54. Mottl MJ, Komor SC, Fryer P, Moyer CL: Deep-slab fluids fuel extremophilic Archaea on a Mariana forearc serpentinite mud volcano: Ocean Drilling Program Leg 195. Geochem Geophys Geosyst 2003, 4:. (electronic journal).

55. Charlou JL, Fouquet Y, Bougault H, Donval JP, Etoubleau J, Philippe JB, Dapoigny A, Appriou P, Rona PA: Intense $\mathrm{CH}_{4}$ plumes generated by serpentinization of ultramafic rocks at the intersection of the $15^{\circ} 20^{\prime} \mathrm{N}$ fracture zone and the Mid-Atlantic Ridge. Geochim Cosmochim Acta 1998, 62:2323-2333.

56. Hinrichs KU, Hayes JM, Bach W, Spivack AJ, Hmelo LR, Holm NG, Johnson CG, Sylva SP: Biological formation of ethane and propane in the deep marine subsurface. Proc Natl Acad Sci USA 2006, 103: | 4684- | 4689.

57. Sposito G, Skipper NT, Sutton R, Park SH, Soper AK, Greathouse JA: Surface geochemistry of the clay minerals. Proc Natl Acad Sci USA 1999, 96:3358-3364.

58. van Groos AF, Guggenheim S: The stability of methane hydrate intercalates of montmorillonite and nontronite: Implications for carbon storage in ocean-floor environments. Am Mineral 2009, 94:372-379.

59. Holm NG, Neubeck A, Ivarsson M, Konn C: Abiotic organic synthesis beneath the ocean floor. In Astrobiology: Emergence, search and detection of Life Edited by: Basiuk V. Valencia, CA: American Scientific Publishers; 2009.

60. Kummer T, Spinelli GA: Hydrothermal circulation in subducting crust reduces subduction zone temperatures. Geology 2008, 36:91-94.

6I. Fryer P, Wheat CG, Mottl MJ: Mariana blueschist mud volcanism: Implications for conditions within the subduction zone. Geology 1999, 27:103-106.

62. D'Antonio M, Kristensen MB: Serpentine and brucite of ultramafic clasts from the South Chamorro Seamount (Ocean Drilling Program Leg 195, Site I 200): Inferences for the serpentinization of the Mariana forearc mantle. Mineral Mag 2004, 68:887-904

63. de Zwart II, Meade SJ, Pratt AJ: Biomimetic phosphoryl transfer catalysed by iron(II)-mineral precipitates. Geochim Cosmochim Acta 2004, 68:4093-4098.

64. Baltcheffsky $\mathrm{H}$, Baltcheffsky M: Molecular origin and evolution of early energy conversion. In Early Life on Earth. Nobel Symposium No. 84 Edited by: Bengtson S. New York: Columbia U.P.; 1994:8I-90.

65. Hüpers $A$, Kopf $A$ ): The thermal influence on the consolidation state of underthrust sediments from the Nankai margin and its implications for excess pore pressure. Earth Planet Sci Lett 2009. doi:10.1016/j.epsl.2009.05.047

66. Haggerty JA: Evidence from fluid seeps atop serpentine seamounts in the Mariana Forearc: Clues for emplacement of the seamounts and their relationships to forearcs tectonics. Mar Geol I99I, 102:293-309.

67. Russell MJ, Hall AJ, Boyce AJ, Fallick AE: On hydrothermal convection systems and the emergence of life. Econ Geol 2005, 100:419-438.

68. Hennet RJC, Holm NG, Engel MH: Abiotic synthesis of amino acids under hydrothermal conditions and the origin of life: $A$ perpetual phenomenon? Naturwissenschaften 1992, 79:361-365.

69. Flanagan G, Ahmed SN, Shevlin PB: Formation of carbohydrates in the reaction of atomic carbon with water. J Am Chem Soc 1992, I | 4:3892-3896.

70. Delacour A, Früh-Green GL, Bernasconi SM, Schaeffer P, Kelley DS: Carbon geochemistry of serpentinites in the Lost City hydrothermal system ( $30^{\circ} \mathrm{N}$, MAR). Geochim Cosmochim Acta 2008, 72:368I-3702.

71. Prieur BE: Étude de l'activité prébiotique potentielle de l'acide borique. Acad C R Sci Paris, Chimie/Chemistry 200I, 4:667-670.
72. Ricardo A, Carrigan MA, Olcott AN, Benner SA: Borate minerals stabilize ribose. Science 2004, 303:196.
Publish with Bio Med Central and every scientist can read your work free of charge

"BioMed Central will be the most significant development for disseminating the results of biomedical research in our lifetime. "

Sir Paul Nurse, Cancer Research UK

Your research papers will be:

- available free of charge to the entire biomedical community

- peer reviewed and published immediately upon acceptance

- cited in PubMed and archived on PubMed Central

- yours - you keep the copyright 